It is likely that with increasing reliability of pacing systems the pacing survival rates will improve further, but pacing systems need highly skilled medical and technical staff and complex equipment for installation and maintenance. For these reasons and because we are dealing with an elderly group of patients, of ten suffering from additional disease, there is still a place for the use of drugs in the treatment of chronic heart block provided patients are carefully selected for this form of therapy.

\section{Selection of Patients for Treatment}

Patients with a long duration of symptoms are more likely to do well on drugs than those with a short history. This cannot be explained by the underlying aetiology, since the length of history gives no clue to the cause of chronic heart block (Harris et al., 1968), but it may be due to the block becoming complete, with less liability to rhythm changes, after a long period of time. The use of a preliminary trial of intravenous isoprenaline has proved a valuable indicator of the likely result of long-term treatment with oral long-acting isoprenaline, and is also of value in avoiding the risk of ventricular tachyrhythmias with long-acting isoprenaline. The majority of patients who have a stable increase in ventricular rate with intravenous isoprenaline will do well on long-acting isoprenaline, and those who have a changing ventricular focus with modest doses of intravenous isoprenaline will respond poorly to oral therapy (Table III). Knowledge of the dysrhythmia in the Adams-Stokes attacks is also of some value in deciding treatment. As expected, patients with ventricular tachyrhythmias usually respond less well to drug therapy than those with attacks due to asystole. Improvement in monitoring systems to record the attack rhythm in a greater percentage of patients may make this correlation closer.

The slectrocardiographic changes have proved less helpful than expected in deciding treatment. About one-third (74) of the 203 patients studied were in sinus rhythm or intermediate heart block (2:1, $3: 1$, etc.) (Table II). There were more patients with these lower grades of block in the group needing pacing to control symptoms ( 42 of $103,41 \%$ ) than in the group which did well on oral long-acting isoprenaline (22 of $72,30 \%$ ), but the difference was not great. While these results tend to confirm the belief that patients with intermittent or incomplete heart block respond less well to drug therapy and commonly need pacing to control symptoms, some remain well on drugs. Most of the patients in sinus rhythm tolerated isoprenaline surprisingly well and only five needed pacing because of intolerable sinus tachycardia produced by the drug. The other 24 patients with sinus rhythm were paced because of continued Adams-Stokes attacks (Table V).

Heart failure with slow ventricular rates responds poorly to isoprenaline (with or without the addition of digitalis in those patients in complete heart block (Table VI). The majority of these patients need artificial pacing to increase the ventricular rate sufficiently. Angina of effort does not improve with the use of isoprenaline and may be made worse, since cardiac work and oxygen consumption are increased.

I would like to thank Dr. Aubrey Leatham for his advice and help in the preparation of this paper and Dr. Ruth Lang for her technical assistance.

Requests for reprints should be sent to Dr. David Redwood, Cardiology Branch, National Institutes of Health, Bethesda, Md. 20014, U.S.A.

\section{REFERENCES}

Aber, C. P., and Wyn Jones, E. (1965). Brit. Heart f., 27, 916.

Bluestone, R., and Harris, A. (1965). Lancet, i, 1299.

Campbell, M. (1944). Brit. Heart 7., 6, 69.

Dack, S. (1963). Amer. Heart 7., 66, 579.

Dack, S. and Robbin, S. R. (1961). F. Amer. med. Ass., 176, 505.

Feil, H. (1923). 7. Amer. med. Ass., 80, 26.

Feil, H. (1923). F. Amer. me. As. A. (1963). Lancet, 2, 214

Fleming, H. A., and Mirams, J. A. (1963). Lancet, 2, 214.

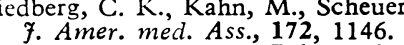

Gilchrist, A. R. (1934). Brit. med. F., 1, 610

Graybiel, A., and White, P. D. (1936). Amer. F. med. Sci., 192, 334.

Harris, A., Davies, M. J., Leatham, A., and Redwood, D. (1968). Unpublished observations.

Johansson, B. W. (1966). Acta med. scand., 180, Suppl. No. 451.

Miller, T. G. (1925). Amer. 7. med. Sci., 170, 157

Nathanson, M. H., and Millcr, H. (1952). Circulation, 6, 238.

Parkinson, I., and Bain, C. W. C. (1924). Lancet, 2, 311 .

Penton, G. B., Miller, H., and Levine, S. A. (1956). Circulation, 13, 801.

Phear, A. G., and Parkinson, J. (1922). Lancet, 1, 933.

Redwood, D. (1968). Brit. med. f., 1, 419

Robbin, S. R., and Dack, S. (1959). Circulation, 20, 757

Robbin, S. R., Goldfein, S., Schwartz, M. J., and Dack, S. (1955). Amer 7. Med., 18, 577 .

Rowe, J. C., and White, P. D. (1958). Ann. intern. Med., 49, 260.

Wood, J. E. (1932). 7. Amer. med. Ass., 98, 1364

\title{
Asymptomatic Urinary Tract Infection in Gynaecological Outpatients
}

\author{
J. D. WILLIAMS,* M.D., D.C.P., M.C.PATH. ; J. L. THOMLINSON, † M.B., M.R.C.O.G.
}

J. G. L. COLE, $\ddagger$ M.B., D.M.R., D.M.R.D. ; E. COPE, $\S$ M.D., F.R.C.O.G.

Brit. med.7., 1969, 1,29-31

\begin{abstract}
Cummary : In this study mid-stream specimens of urine were collected from all new patients attending a gynaecological outpatient department and tested for significant bacteriaria. Those having an asymptomatic infection were followed up, treated, and investigated radiologically.

Of 1,506 women screened for bacteriuria $82(5.4 \%)$ were found to have a persistent infection. The predominant organism was Escherichia coli, present in $83 \%$ of infections. Treatment with sulphonamides produced a good cure rate, which was improved by ampicillin given to failures. Some patients, however, had infections that persisted or recurred despite several antibiotics. The radiological investigations showed that a high proportion of women with asymptomatic urinary infection had severe renal disease which was quite symptomless. This was more pronounced in those with persistent or recurrent infections.
\end{abstract}

\section{Introduction}

The presence of a significant bacteriuria, defined as over 100,000 or more organisms per ml. of urine (Kass, 1956), has been found to occur in $5 \%$ of pregnant women and to be equally or more prevalent among diabetics, elderly patients, and some other population groups. In pregnancy this bacteriuria is often associated with renal abnormality (Kincaid-Smith and Bullen, 1965) and is usually asymptomatic.

We have studied women attending a gynaecological outpatient department to find the incidence of asymptomatic infection present in this group of patients, to determine if any

* Consultant Bacteriologist, Dudley Road Hospital, Birmingham 18 t Registrar, Department of Obstetrics and Gynaecology, Dudley Road Hospital, Birmingham 18. Present address: Department of Obstetric and Gynaecology, Hammersmith Hospital, London W.12. $\ddagger$ Consultant Radiologist, Dudley Road Hospital, Birmingham 18.

Consultant Obstetrician and Gynaecologist, Dudley Road Hospital, Birmingham 18. Present address: The Nuffield Maternity Home, Walton Street, Oxford. 
particular gynaecological disorder predisposed to urinary tract infection, and to discover if infection was associated with renal disease.

\section{Patients and Methods}

Mid-stream specimens of urine were collected from 1,506 women attending for the first time at a gynaecological clinic. The organization of the clinic was similar to that described in previous surveys (Williams et al., 1965). Patients having a bacteriuria of over 100,000 organisms per ml. were recalled for confirmatory specimens and were regarded as having persistent bacteriuria if two or more consecutive specimens of urine contained over 100,000 organisms of the same bacterial species.

Initial urine screening was carried out by the blotting-paper strip method (Leigh and Williams, 1964) with confirmation by means of surface viable counts on MacConkey agar. Organisms were identified by standard methods and white cells were counted in a Fuchs-Rosenthal chamber.

For initial treatment infected patients were given an eightday course of sulphadimidine $1 \mathrm{~g}$. six-hourly or hexamine hippurate (Hippramine) $1 \mathrm{~g}$. twice daily. Patients whose infections failed to respond to this treatment then received an eightday course of ampicillin $500 \mathrm{mg}$. three times daily. The effectiveness of treatment was assessed in specimens of urine collected one week and five weeks after the end of treatment.

Intravenous pyelography was performed on 46 women with persistent bacteriuria after this had been treated.

Blood pressure was measured sitting in all patients having intravenous pyelography and venous blood taken for blood urea determination.

\section{Results}

Of the 1,506 women tested, $82(5.4 \%)$ were confirmed as having persistent bacteriuria (Table I). A further 45 who were found to have a bacteriuria or who had an equivocal specimen on the first visit were not so confirmed owing to failure to attend the clinic (15 cases) or because of negative findings in the second specimen (30 cases). The organisms isolated causing persistent bacteriuria were found to be Escherichia coli in $83 \%$ of cases (Table I).

TABLE I.-Incidence of Asymptomatic Infection and Causative Organisms in 1,506 Patients Tested

$\begin{array}{ccccc}\text { Persistent bacteriuria } & \ldots & \ldots & \ldots & 82 \\ \text { Escherichia coli } & (5 \cdot 4 \%) & \\ \text { Atypical coliforms } & \ldots & \ldots & \ldots & 68 \\ \text { Proteus mirabilis } & \ldots & \ldots & \ldots & 6 \\ \text { Klebsiella spp. } & \ldots & \ldots & \ldots & 2 \\ \text { Staphylococcus albus } & \ldots & \ldots & \ldots & 2\end{array}$

Over $10 \%$ of the women with prolapse, fibroids, or infertility had infected urine, but infections were present in all the clinical groups of patients (Table II). A short course of sulphadimidine cleared 28 of the 38 patients treated; six of these were either reinfected or relapsed later, giving an initial cure rate of $73 \%$, later falling to $58 \%$ (Table III). Hexamine hippurate was less effective, $17(50 \%)$ of 34 patients still being infected after

TABLE II.-Incidence of Asymptomatic Infection in Patients Presenting with Various Gynaecological Disorders

\begin{tabular}{|c|c|c|c|c|}
\hline \multicolumn{2}{|l|}{ Clinical group } & $\begin{array}{l}\text { No. of } \\
\text { Patients }\end{array}$ & $\begin{array}{c}\text { No. with } \\
\text { bacteriuria }\end{array}$ & Incidence \\
\hline 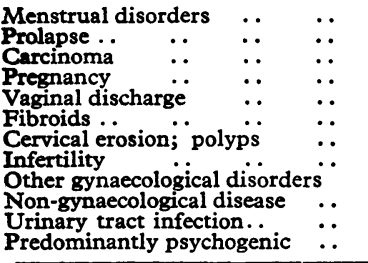 & $\begin{array}{l}\because \\
\because \\
\because \\
\because \\
\because \\
\therefore \\
\because \\
\because\end{array}$ & $\begin{array}{r}435 \\
105 \\
24 \\
37 \\
244 \\
37 \\
187 \\
53 \\
87 \\
58 \\
5 \\
234\end{array}$ & $\begin{array}{r}13 \\
10 \\
5 \\
2 \\
15 \\
4 \\
8 \\
5 \\
8 \\
3 \\
4 \\
5\end{array}$ & $\begin{array}{l}3 \% \\
10 \% 5 \% \\
20 \% \\
6 \% \\
7 \% \\
11 \% \\
5 \% \\
10 \% \\
9 \% \\
5 \% \\
80 \% \\
2 \%\end{array}$ \\
\hline Total & .. & 1,506 & 82 & $5 \cdot 4 \%$ \\
\hline
\end{tabular}

treatment and a further two becoming infected during a followup (Table III).

TABLE III.-Response of Bacteriuria to Treatment

\begin{tabular}{|c|c|c|c|c|c|}
\hline & & & $\begin{array}{c}\text { No. } \\
\text { Treated }\end{array}$ & $\begin{array}{l}\text { Clear after } \\
\text { Treatment }\end{array}$ & Relapse \\
\hline $\begin{array}{l}\text { Primary treatment: } \\
\text { Sulphonamides } \\
\text { Hexamine hippurate ... } \\
\text { Secondary treatment: } \\
\text { Ampicillin .. .. }\end{array}$ & $\begin{array}{l}\cdots \\
\cdots \\
\ldots\end{array}$ & $\begin{array}{l}\cdots \\
\cdots \\
\ldots\end{array}$ & $\begin{array}{l}38 \\
34 \\
23\end{array}$ & $\begin{array}{l}28(73 \%) \\
17(50 \%) \\
15(65 \%)\end{array}$ & $\begin{array}{l}6(15 \%) \\
2(6 \%) \\
1(4 \%)\end{array}$ \\
\hline
\end{tabular}

Twenty-three patients who had failed to respond to initial treatment received ampicillin and $15(65 \%)$ of these responded, one relapsing later (Table III). Three patients failing to respond to hexamine hippurate were given sulphadimidine and one had nitrofurantoin. Sixteen patients were lost to follow-up during the study, but in 66 a full assessment of the results of treatment could be made and in 46 of these intravenous pyelography was performed. The abnormalities detected are shown in Table IV. Of the pyelograms 26 were normal and $19(41 \%)$ abnormal.

TABLE IV.-Radiological Findings on Intravenous Pyelography with with Urinary Infection

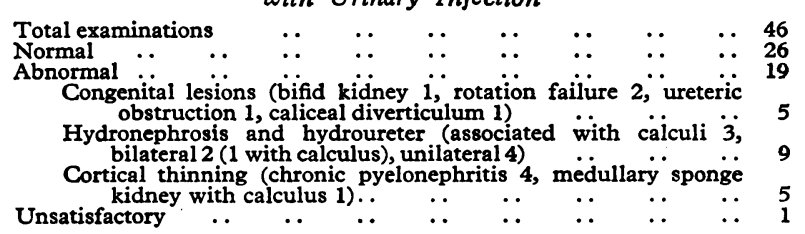

The relationship of the urinary tract abnormalities to the response to treatment is shown in Table $\mathrm{V}$. Of 12 patients with persistent or repeated infection, $8(66 \%)$ had abnormalities, and these were generally major, a calculus occurring in four. However, even in those who responded to one or two courses of therapy some urinary tract abnormalities were present in 30 and $60 \%$ respectively.

TABLE V.-Retationship of $\underset{\text { Treatment }}{\text { Abnormal Pyelograms to Response to }}$

\begin{tabular}{c|c|c|c|c}
\hline Treatment Category & $\begin{array}{c}\text { No. of } \\
\text { Patients }\end{array}$ & $\begin{array}{c}\text { No } \\
\text { Pyelogram }\end{array}$ & $\begin{array}{c}\text { Normal } \\
\text { Pyelogram }\end{array}$ & $\begin{array}{c}\text { Abnormal } \\
\text { Pyelogram }\end{array}$ \\
\hline Cleared with one course of treatment & 36 & 17 & 13 & $6(30 \%)$ \\
Cleared with two courses of treatment & 18 & 3 & 6 & $9(60 \%)$ \\
Persistent and recurrent infections.. & 12 & 0 & 4 & $8(66 \%)$ \\
\hline
\end{tabular}

The results of blood pressure readings and blood urea are shown in Table VI. The mean systolic and diastolic blood pressures were greater in patients with radiographic abnormalities. Seven patients had a diastolic blood pressure of $100 \mathrm{~mm}$. $\mathrm{Hg}$ or more, five of these also having an abnormal pyelogram. One patient with bilateral pyelonephritis had a blood urea of $62 \mathrm{mg} . / 100 \mathrm{ml}$. but in all the other patients urea levels were below $45 \mathrm{mg} . / 100 \mathrm{ml}$.

TABLE VI.-Blood Pressure and Blood Urea Findings in Patients Having

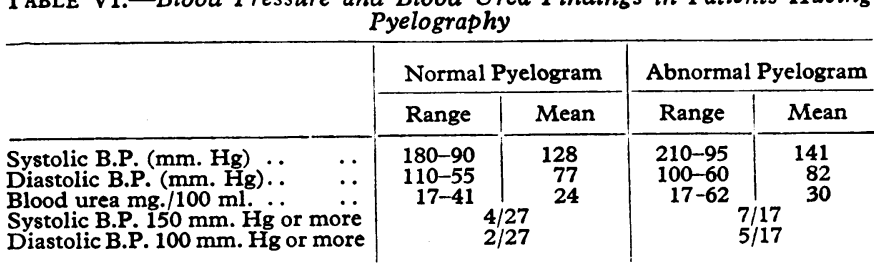

\section{Discussion}

Almost all women suffer at some time from symptomatic ascending urinary tract infections, which are treated by their medical attendants. However, many studies on pregnant women have shown the incidence of asymptomatic infection to be also 
high (Kass, 1960 ; Turner, 1961 ; Kincaid-Smith et al., 1964). Repeated or persistent infection is held to be the major factor in the development of chronic pyelonephritis (Brumfitt and Percival, 1964), and it is hoped that by the detection and treatment of acute or unsuspected infections the incidence of chronic renal failure may be reduced.

This study of a group of non-pregnant women has shown that the incidence of unsuspected infection (5.3\%) is similar to that found in pregnant women. The detection of these infections is relatively simple, and the screening of all women attending gynaecological outpatient departments and the treatment of those infected may be of value. Though some variation in incidence was found in differing gynaecological conditions, infections were present in all groups. The incidence among women whose prime complaint was infertility was higher than that found in pregnancy and similar to the incidence of $8 \%$ mentioned by Sleigh et al. (1964).

The organisms causing the infections were similar to those in bacteriuria of pregnancy, with $E$. coli predominating. A higher incidence of pyuria was present, however, among gynaecological patients than in pregnancy bacteriurias (Williams et al., 1965).

In the majority of cases a short course of a sulphonamide was sufficient to clear the infection, and ampicillin cured many of those failing to respond to sulphonamides. Only $12(18 \%)$ of the 66 patients closely followed up proved resistant to treatment, and eight of these had abnormal pyelograms. Among those who responded to simple therapy, abnormalities were also found on pyelography, but they were usually of minor importance, and it was among the more resistant infections that the major disease, such as the presence of calculus, was found. The short courses of treatment given in this study helped us to discover those patients whose severe underlying renal disease failed to respond to the simpler measures.

The role which asymptomatic infection plays in the development of progressive renal damage is not clear, but the presence of infection, often associated with hypertension, is a pointer to existing renal disease needing treatment.

Though treatment is easy to administer the follow-up of these patients is difficult within the resources of gynaecological clinics. The amount of occult renal disease found in this survey, however, suggests that consideration be given to the provision of facilities for urine screening and adequate follow-up.

\section{REFERENCES}

Brumfitt, W., and Percival, A. (1964). F. clin. Path., 37, 482.

Kass, E. H. (1956). Trans. Ass. Amer. Phycns, 69, 56.

Kass, E. H. (1960) Arch. intern. Med., 105, 194.

Kincaid-Smith, P., and Bullen, M. (1965). Lancet, 1, 395.

Kincaid-Smith, P., Bullen, M., Mills, J., Fussell, U., Huston, N., and Goon, F.'(1964). Lancet, $2,61$.

Leigh, D. A., and Williams, J. D. (1964). 7. clin. Path., 17, 498.

Sleigh, J. D., Robertson, J. G., and Isdale, M. H. (1964). F. Obstet. Gynaec. Brit. Cwlth, 71, 74.

Turner, G. C. (1961). Lancet, 2, 1062.

Williams, J. D., Leigh, D. A., Rosser, E. ap I., and Brumfitt, W. (1965).

f. Obstet. Gynaec. Brit. Cwlth, 72, 327.

\title{
Effect of Salbutamol on Spirometry and Blood-gas Tensions in Bronchial Asthma
}

\author{
K. N. V. PALMER,* M.D., F.R.C.P., M.R.C.P.ED. ; M. L. DIAMENT, $\dagger$ M.D.
}

\begin{abstract}
Cummary : A new bronchodilator drug, salbutamol, $S$ reduced airway obstruction in 37 patients with bronchial asthma but did not lead to a significant fall in lowered arterial oxygen tension. This drug, unlike other bronchodilators, appears to have little or no effect on the cardiovascular system, and it is suggested that it does not therefore lead to an intensification of the ventilation/perfusion disturbance in the lung leading to a worsening of hypoxaemia.
\end{abstract}

\section{Introduction}

Sympathomimetic drugs are much used to reverse or decrease the widespread small airway obstruction which characterizes attacks of bronchial asthma. However, deaths from asthma have risen progressively during the past decade, and the increase in the use of pressurized aerosols, most often containing isoprenaline, correlates closely with the increase in asthma mortality in Britain (Speizer et al., 1968). Isoprenaline is a powerful stimulant of $\beta$-adrenergic receptors in both bronchial and cardiac muscle, so that in addition to relaxing the smooth muscle of the bronchi it increases cardiac output and dilates the pulmonary vasculature (Aviado and Schmidt, 1957). Probably as a direct consequence of its action on the cardio-

* Reader in Medicine, University of Aberdeen.

† Lecturer in Physiology, University of Aberdeen. vascular system, even though airway obstruction is diminished, there may be no increase in lowered arterial oxygen tensions, and indeed in many instances the degree of hypoxaemia may become worse afterwards (Knudson and Constantine, 1967 ; Field, 1967 ; Palmer and Diament, 1967). The decrease in arterial oxygen saturation in patients already hypoxaemic as a result of the asthma attack is clearly undesirable; moreover, it has been suggested that the stimulant effect of isoprenaline on the hypoxaemic myocardium may lead to ventricular irritability and fatal arrhythmia (Speizer et al., 1968).

We report here the effect, when given by aerosol inhalation, of a new selective $\beta$-adrenergic stimulant (salbutamol) on spirometric and blood-gas tension measurements in asthmatic subjects. This drug is a potent and long-lasting stimulator of $\beta$-adrenergic receptors in bronchial muscle, but has relatively little effect on the cardiovascular system (Brittain et al., 1968), and might therefore be expected to reduce increased airway resistance without a concomitant fall in $\mathrm{PaO}_{2}$.

\section{Patients and Methods}

Thirty-seven patients were investigated. Their mean age was 45.6 years $( \pm 14.0)$. They had been admitted to hospital in status asthmaticus and had a long history of attacks of acute airway obstruction with little or no disability between attacks. All had either blood or sputum eosinophilia, and the majority had both. Blood samples were obtained in a heparin-lubricated 